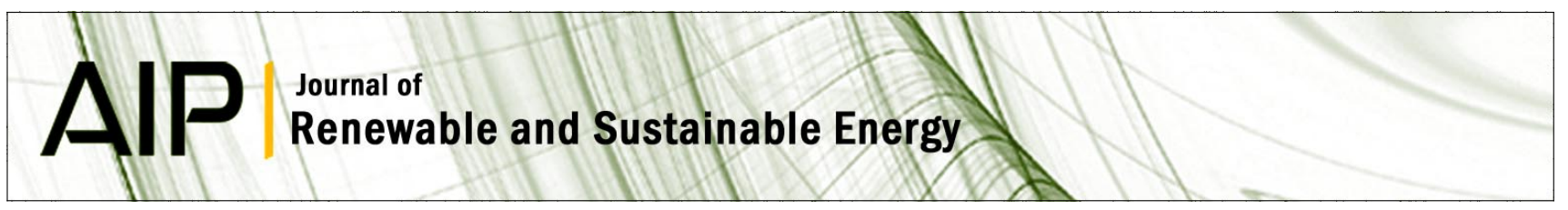

\title{
OCCAM: On-line cost-function based control algorithm for microgrids
}

Eduardo Alvarez Alvarez, Antonio M. Campos López, and Antonio J. Gutiérrez-Trashorras

Citation: J. Renewable Sustainable Energy 4, 033101 (2012); doi: 10.1063/1.4712048

View online: http://dx.doi.org/10.1063/1.4712048

View Table of Contents: http://jrse.aip.org/resource/1/JRSEBH/v4/i3

Published by the American Institute of Physics.

\section{Related Articles}

Incorporation of plug in hybrid electric vehicle in the reactive power market J. Renewable Sustainable Energy 4, 053123 (2012)

Equity dimensions of micro-generation: A whole systems approach J. Renewable Sustainable Energy 4, 053122 (2012)

An earth-isolated optically coupled wideband high voltage probe powered by ambient light Rev. Sci. Instrum. 83, 104703 (2012)

Reduction in subsidy for solar power as distributed electricity generation in Indian future competitive power market

J. Renewable Sustainable Energy 4, 053120 (2012)

Optimized working conditions for a thermoelectric generator as a topping cycle for gas turbines

J. Appl. Phys. 112, 073515 (2012)

\section{Additional information on J. Renewable Sustainable Energy}

Journal Homepage: http://jrse.aip.org/

Journal Information: http://jrse.aip.org/about/about_the_journal

Top downloads: http://jrse.aip.org/features/most_downloaded

Information for Authors: http://jrse.aip.org/authors

\section{ADVERTISEMENT}

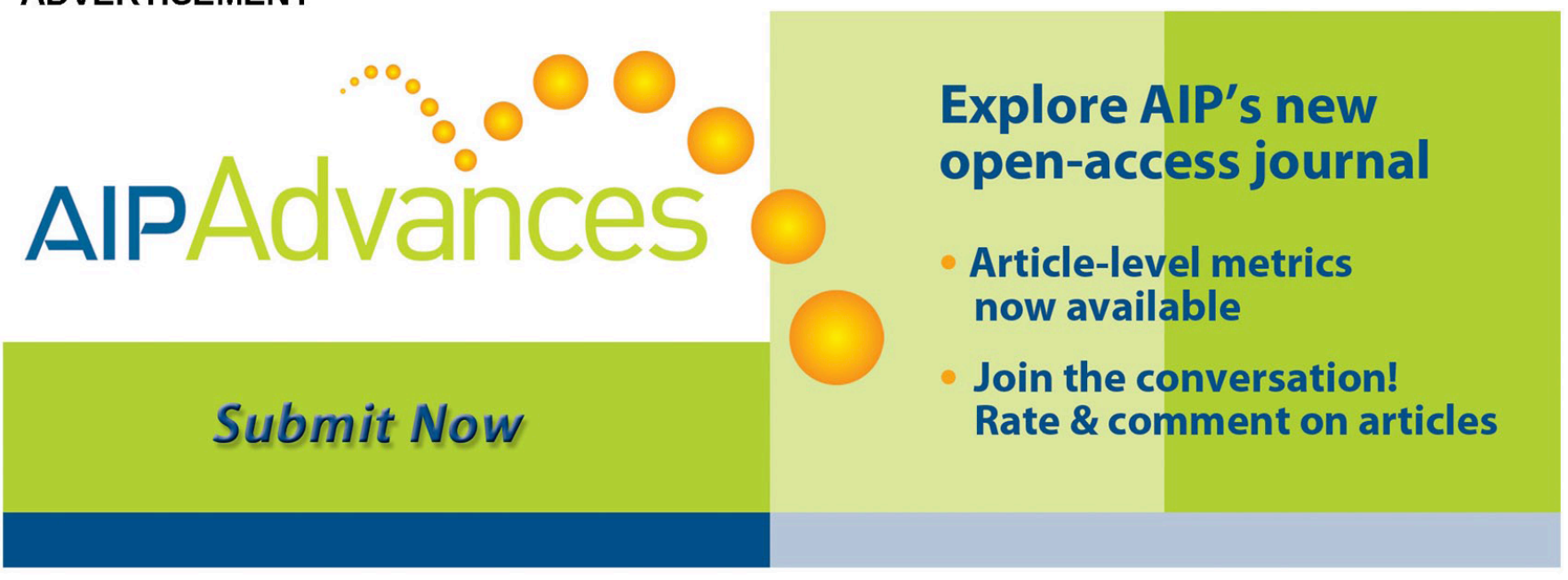




\title{
OCCAM: On-line cost-function based control algorithm for microgrids
}

\author{
Eduardo Alvarez Alvarez, ${ }^{1, a)}$ Antonio M. Campos López, ${ }^{1}$ \\ and Antonio J. Gutiérrez-Trashorras ${ }^{2}$ \\ ${ }^{1}$ Fundación CTIC, C/Ada Byron, 39 Edificio Centros Tecnológicos, 33203 Gijón, Asturias, \\ Spain \\ ${ }^{2}$ Energy Department, University of Oviedo, C/Independencia 13, 33004 Oviedo, Asturias, \\ Spain
}

(Received 15 November 2011; accepted 20 April 2012; published online 7 May 2012)

This paper presents the active power dispatching of microsources, as an on-line minimization problem, including electrical and heat generation costs. The use of a new algorithm: on-line cost-function based control algorithm for microgrids (OCCAM), makes it possible to obtain similar or even better solutions than those obtained using other state of the art methods like MADS and SQP. Moreover, its execution time is about one hundred times lower than the time needed by other algorithms and it can run efficiently on-line. OCCAM is based on the same principle as the famous William Occam's razor: "the simplest explanation is most likely the correct one"; its simplicity is the reason for its low execution time. It uses costs functions of microsources and heat savings (obtained by recovering heat from microsources in cogeneration installations) to determine the optimal solution. (C) 2012 American Institute of Physics. [http://dx.doi.org/10.1063/1.4712048]

\section{INTRODUCTION}

Microgrids integrating renewable and non-renewable generators are often thought of as a future solution to the growing electrical and heat demand. Generators are located close to the points of demand, reducing electrical losses and allowing heat to be recovered using cogeneration (CHP) installations. Furthermore, microgrids make it possible to combine renewable and non-renewable energy sources to guarantee low-cost electrical power and to minimize environmental impact.

Nevertheless, massive non-controlled microgrids penetration in the distribution grid may have negative effects on the global efficiency of the electrical system. The experience shows that they may cause increased distribution losses, invalid protection and measurement systems, and instability. Even worse, non-controlled microgrids may not attain low-cost energy and they could have highly negative environmental impact due to gas emissions.

As the potential benefits outweigh the problems, various research lines have followed different approaches to minimize the negative effects of microgrids. The main studied factors have been: electrical generation costs, on-line adaptation to electrical demand, gas emissions or the economic and environmental implications of heat demand.

This work presents a heuristic algorithm to on-line dispatch of electrical active power in a microgrid. The approach has two optimization criteria. The first one is to minimize the global cost of active power and heat generation. Both include economic and environmental estimated costs. The second one is to adjust electrical production to the demand while reducing the electrical impact on the distribution system. This new algorithm is called "OCCAM: on-line costfunction based control algorithm for Microgrids." It is based on the same principle as William

\footnotetext{
a) Author to whom correspondence should be addressed. Electronic mail: eduardo.alvarez@fundacionctic.org. Tel.: +34984291212 . 
Occam's razor "the simplest explanation is most likely the correct one." In this research, test results obtained using OCCAM are compared with results using state of the art methods to solve the dispatching problem. It was obtained obtaining similar economical cost and improved emissions cost results, with more stable microsource running conditions. It also needs less computational resources and execution times that it can run on-line in an off-the-shelf controller.

\section{RELATED WORK}

Due to their technical and economic implications in the design and operation of microgrids, most of the papers on this topic are related to the optimal sizing of microsources and the functionality of electrical power dispatch.

Some of the latest researchers in the optimum size of microgrids have been developed by Mohammadi et al. ${ }^{1}$ and Moghaddas-Tafreshi et $a l^{2}{ }^{2}$ The functionality of power dispatch is included in microgrid management systems. References 3 and 4 review the state of the art of the different systems. They are usually designed from one of three perspectives: seamless integration of microgrids into the electrical system, fully assuming the internal load; integration of microsources in the electrical power market; and minimization of the economic and environmental cost of non-renewable microsources.

The first perspective is the focus of the research from the United States Consortium for Electric Reliability Technology Solutions (CERTS). The Consortium has designed a distributed control system based on microsource local controllers that guarantees seamless integration with the grid, but without optimization of the economic and environmental generation costs. ${ }^{5}$

The second perspective has been developed within the project MICROGRIDS financed by the European Fifth Framework Programme. ${ }^{6}$ The design has a centralized control system in which active power set points are generated by a complex software tool. This tool is based on environmental and market predictions, with the objective of optimizing economic benefits. ${ }^{7}$ These set-points are dispatched $24 \mathrm{~h}$ in advance to non-renewable microsources. In this case there is no on-line adaptation to possible variations in the consumption, therefore the impact on the main grid is not guaranteed. Continuing with this line of investigation, special emphasis has been put to include thermal generation and energy storage regulation. ${ }^{8}$

The third perspective is focused on minimizing fuel consumption and gas emissions as well as adjusting on-line microgrid electrical and heat production to the demand. These principles were first proposed in Ref. 9 looking for unnoticed integration in the system. As the economic implications of reactive power are minimal, efforts have been focused on the active power dispatch problem. Recent research ${ }^{10-12}$ defines this problem as an on-line minimization of a high non-linear function usually with non-linear constrains (technical limits of the microsources and electrical generation equal to demand). The algorithms proposed to find the optimal active power set-points are state-of-the-art mathematical methods to solve a non-linear function optimization with restrictions (mesh adaptive direct search (MADS) and sequential quadratic programming (SQP)). The MADS algorithm is an iterative method which uses a mesh methodology to find successive points that improve solutions in reference to the objective. The SQP method finds an optimal solution with the iterative use of gradients of the objective function. In the most recent research, the best results were obtained applying the MADS method. But the computational resources needed to run on-line have not been evaluated.

This work presents an algorithm (OCCAM) designed to solve with minimum computational resources, a microgrid active power dispatch problem. The procedure minimizes all energy costs involved in electrical power and heat generation, achieving an on-line adaptation to the electrical demand while assuring the heat request.

\section{PROBLEM DEFINITION}

Generically a microgrid arrangement (see Fig. 1) is composed of:

- $\mathrm{N}$ microsources, connected to the distribution system at only one point of common coupling. ${ }^{13,14}$

- M heat generators. 


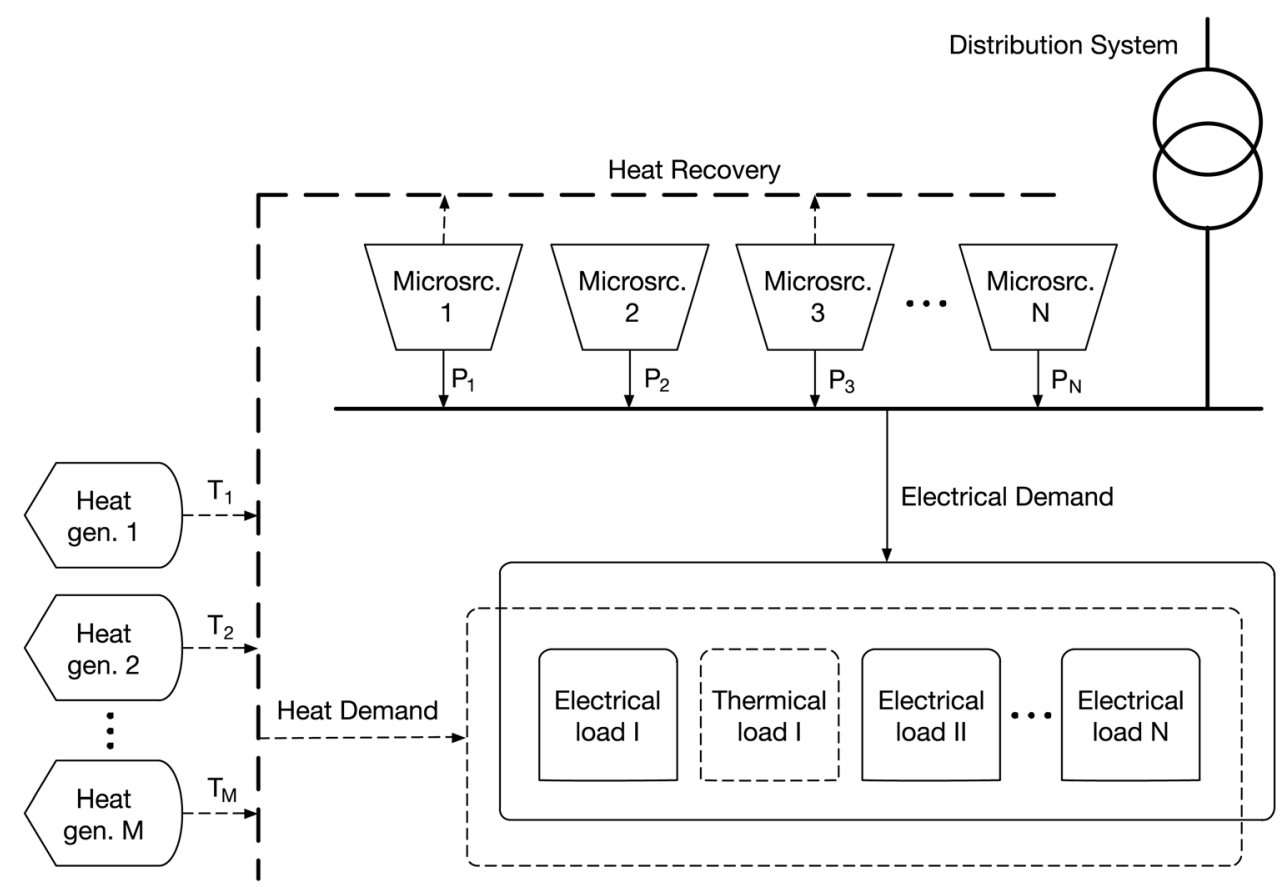

FIG. 1. Microgrid arrangement.

- An electrical demand.

- A heat demand.

- A heat recovery in CHP installations. on line,

The problem to solve may be defined as the minimization of a global energy cost function

$$
\mathrm{C}(\overline{\mathrm{P}}, \overline{\mathrm{T}})=\sum_{\mathrm{i}=1}^{\mathrm{i}=\mathrm{N}} \mathrm{P}_{\mathrm{i}} \cdot \mathrm{f}_{\mathrm{i}}\left(\mathrm{P}_{\mathrm{i}}\right)+\sum_{\mathrm{i}=1}^{\mathrm{i}=\mathrm{M}} \mathrm{T}_{\mathrm{i}} \cdot \mathrm{h}_{\mathrm{j}}\left(\mathrm{T}_{\mathrm{j}}\right)
$$

With the constraints of,

$$
\begin{gathered}
\sum_{\mathrm{i}=1}^{\mathrm{i}=\mathrm{N}} \mathrm{P}_{\mathrm{i}}=\mathrm{ED} \\
\sum_{\mathrm{j}=1}^{\mathrm{j}=\mathrm{M}} \mathrm{T}_{\mathrm{j}} \geq \mathrm{TD} \\
\operatorname{MinP}_{\mathrm{i}} \leq \mathrm{P}_{\mathrm{i}} \leq \operatorname{MaxP}_{\mathrm{i}} \\
\operatorname{MinT}_{\mathrm{j}} \leq \mathrm{T}_{\mathrm{j}} \leq \operatorname{MaxT}_{\mathrm{j}},
\end{gathered}
$$

where

- $\mathrm{C}(\overline{\mathrm{P}}, \overline{\mathrm{T}}),(\$ / \mathrm{h})$ is the global energy cost in the microgrid.

- $\overline{\mathrm{P}}=\left(\mathrm{P}_{1}, \ldots, \mathrm{P}_{\mathrm{i}}, \ldots, \mathrm{P}_{\mathrm{N}}\right),(\mathrm{kW})$ is the vector corresponding to the microsources active power generation levels.

- $\overline{\mathrm{T}}=\left(\mathrm{T}_{1}, \ldots, \mathrm{T}_{\mathrm{j}}, \ldots, \mathrm{T}_{\mathrm{M}}\right),(\mathrm{kW})$ is the vector corresponding to heat generation levels.

- $\mathrm{f}_{\mathrm{i}}\left(\mathrm{P}_{\mathrm{i}}\right),(\$ / \mathrm{kWh})$ is the cost function associated to each microsource: the sum of fuel and emissions cost function. $\mathrm{f}_{\mathrm{i}}\left(\mathrm{P}_{\mathrm{i}}\right)=\mathrm{g}_{\mathrm{i}}\left(\mathrm{P}_{\mathrm{i}}\right)+\mathrm{e}_{\mathrm{i}}\left(\mathrm{P}_{\mathrm{i}}\right)$ (see Fig. 2) 


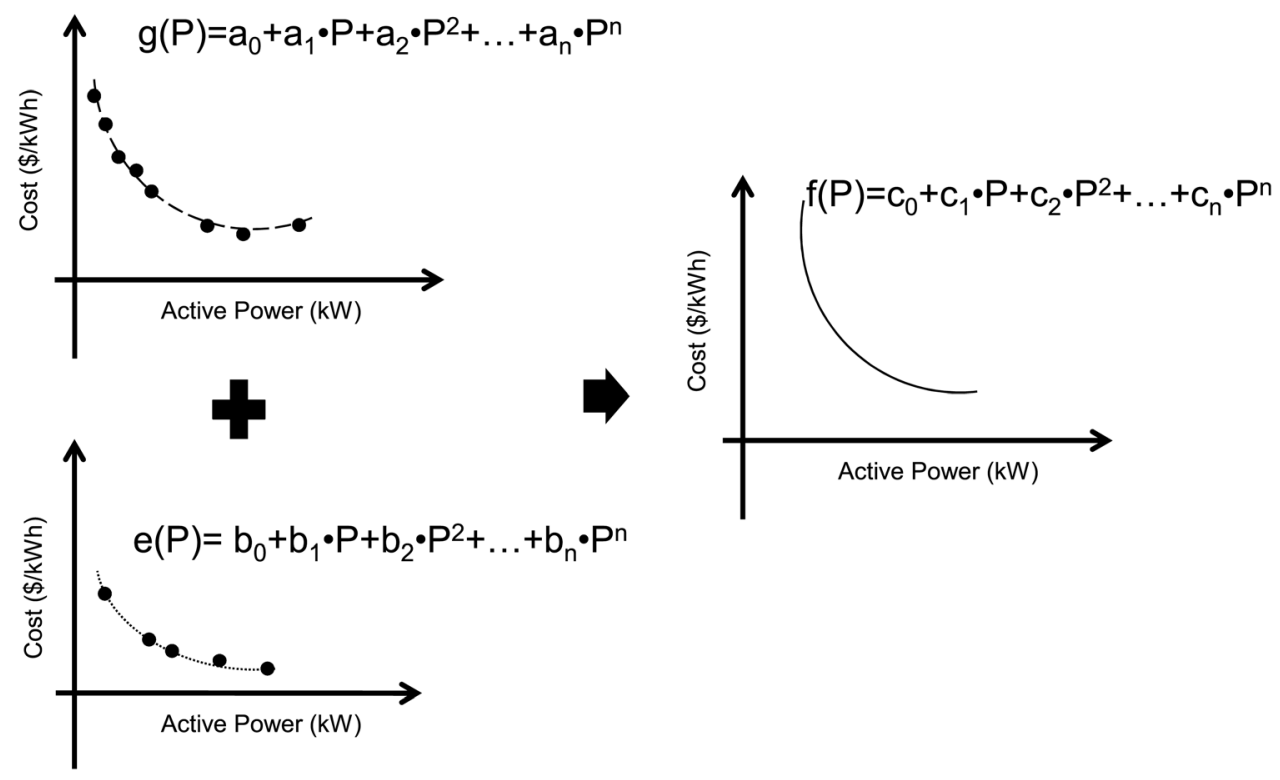

FIG. 2. Microgrid cost function determination.

- $\mathrm{g}_{\mathrm{i}}\left(\mathrm{P}_{\mathrm{i}}\right),(\$ / \mathrm{kWh})$ is the fuel consumption cost function. It is obtained from microsource efficiency at different power levels and the current fuel cost. The procedure uses a least squares technique to obtain a continuous function.

- $\mathrm{e}_{\mathrm{i}}\left(\mathrm{P}_{\mathrm{i}}\right),(\$ / \mathrm{kWh})$ is the emissions cost function. It is obtained from the type of gas emissions, cost associated to the removal of each contaminant $(\$ / \mathrm{kg})$, emissions factor associated with the active power production $(\mathrm{kg} / \mathrm{kW})$ and the fuel consumption data provided by the manufacturer.

- $\mathrm{ED},(\mathrm{kW})$ is the instantaneous value of the electrical active power demand.

- $h_{j}\left(T_{j}\right),(\$ / k W h)$ is the cost function associated with each heat generator. Like the microsource cost function, it is obtained taking into account both the fuel and the emissions cost function. Usually, as the efficiency is quite uniform in the operating range, the cost per $\mathrm{kWh}$ could be considered to be constant.

- TD, $(\mathrm{kW})$ is the instantaneous value of the heat power demanded from the heat generators: the total heat demand minus the heat recovered in CHP installations.

- Min $\mathrm{P}_{\mathrm{i}}$ and Max $\mathrm{P}_{\mathrm{i}},(\mathrm{kW})$ are the technical limits of the active power generated by a microsource.

- Min $\mathrm{T}_{\mathrm{j}}$ and $\operatorname{Max} \mathrm{T}_{\mathrm{j}},(\mathrm{kW})$ are the technical limits of heat power generated by a heat generator.

\section{OCCAM: ON-LINE COST-FUNCTION BASED CONTROL ALGORITHM FOR MICROGRIDS}

The new OCCAM algorithm is designed to be implemented in the Central Controller of a control management system, which could also include local microsources and heat generators controllers (Fig. 3).

In the minimization problem solution, the renewable microsources are allowed to generate all the energy possible. It is supposed that renewable generation capacity is dimensioned to cover only the base electrical load to avoid grid integration problems due to a high level of exportation.

As renewable energies take precedence, OCCAM uses the remaining non-renewable and storage devices cost functions as well as the economic savings obtained by heat recovering in CHP installations to achieve the optimum solution. The algorithm is characterized by its simplicity ("the simplest explanation is most likely the correct one") which is the reason for its minimum execution time. 


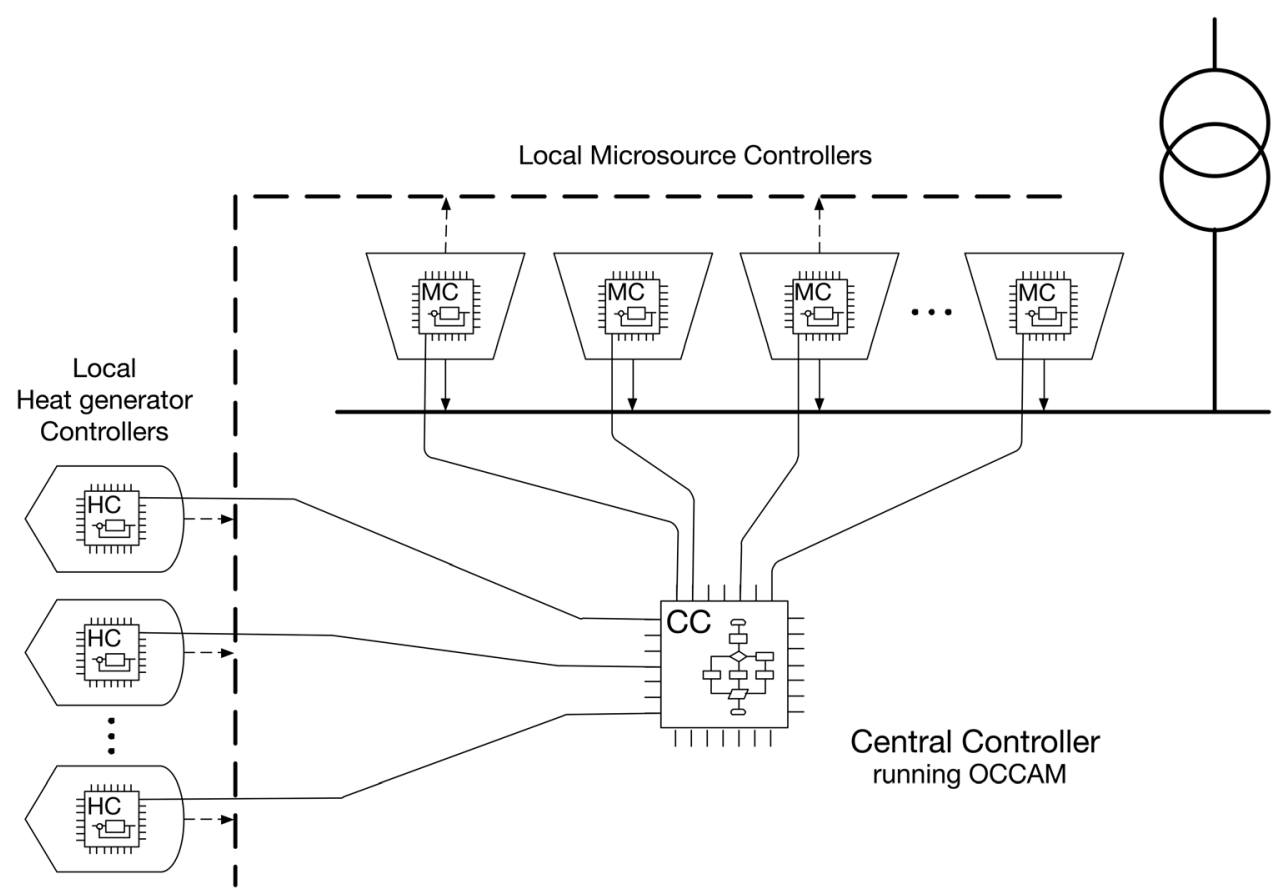

FIG. 3. Central control management system.

Savings $\left(\mathrm{P}_{\mathrm{i}}\right)(\$ / \mathrm{kWh})$, the function used for the evaluation of the heat recovery savings from microsources in CHP installations, is calculated as the minimum cost of producing the same quantity of heat in the generators of the microgrid.

OCCAM is divided into tasks to be executed sequentially (see Fig. 4):

- Task 0: Reset production levels. Set $P_{i}=0$ for every microsource and $T_{j}=0$ for every heat generator.

- Task 1: Read active electrical power generation of renewable microsources $\left(\mathrm{P}_{\mathrm{Ri}}\right)$, and electrical and heat demand (ED, HD). Calculate the remaining electrical demand: $R E D=E D-P_{R i}$.

- Task 2: If the total power generated by renewable microsources is higher than the electrical demand $(\mathrm{RED}<0)$, then charge the storage devices and continue in Task 7 . Else the algorithm continues.

Only for not assigned non-renewable microsources or energy storage devices:

- Task 3: Set preliminary power generation levels of each microsource $\left(\mathrm{U}_{\mathrm{i}}\right)$ to its technical maximum generation level $\left(\mathrm{MaxP}_{\mathrm{i}}\right)$ or to the RED if this demand is smaller than the maximum microsource capacity $\left(\mathrm{RED}<\mathrm{MaxP}_{\mathrm{i}}\right)$.

- Task 4: Calculate generation cost, $\mathrm{f}_{\mathrm{i}}\left(\mathrm{U}_{\mathrm{i}}\right)$ or $\mathrm{f}_{\mathrm{i}}\left(\mathrm{U}_{\mathrm{i}}\right)$-Savings $\left(\mathrm{U}_{\mathrm{i}}\right)$ in case of cogeneration installations.

- Task 5: Assign active power level to the microsource with lowest cost of generation. Calculate the new value of remaining electrical demand $\left(\mathrm{RED}=\mathrm{RED}-\mathrm{U}_{\text {assigned }}\right)$.

- Task 6: If any electrical demand is not yet assigned (RED $>0$ ) and there are microsources without any assignation, the algorithm continues its execution in Task 3. Otherwise skip forward to Task 7.

- Task 7: If there is heat demand not covered in cogeneration installations, it is distributed into different heat generators sequentially from the minimum to the maximum generation cost $\left(\mathrm{T}_{\mathrm{j}}(\mathrm{kW})\right.$ set-points).

- Task 8: Send generation levels $P_{i}$ and $T_{j}$, and return to Task 0 .

For example, a microgrid includes five microsources $\left(\mathrm{m}_{1}, \mathrm{~m}_{2}, \mathrm{~m}_{3}, \mathrm{~m}_{4}, \mathrm{~m}_{5}\right)$.

$\mathrm{m}_{1}, \mathrm{~m}_{2}, \mathrm{~m}_{3}$ are non-renewable microsources with costs functions associated: $\mathrm{f}_{1}\left(\mathrm{P}_{1}\right), \mathrm{f}_{2}\left(\mathrm{P}_{2}\right)$, $\mathrm{f}_{3}\left(\mathrm{P}_{3}\right) \cdot \mathrm{m}_{4}$ is a renewable microsource and $\mathrm{m}_{5}$ is a battery. The battery is assumed to have a 


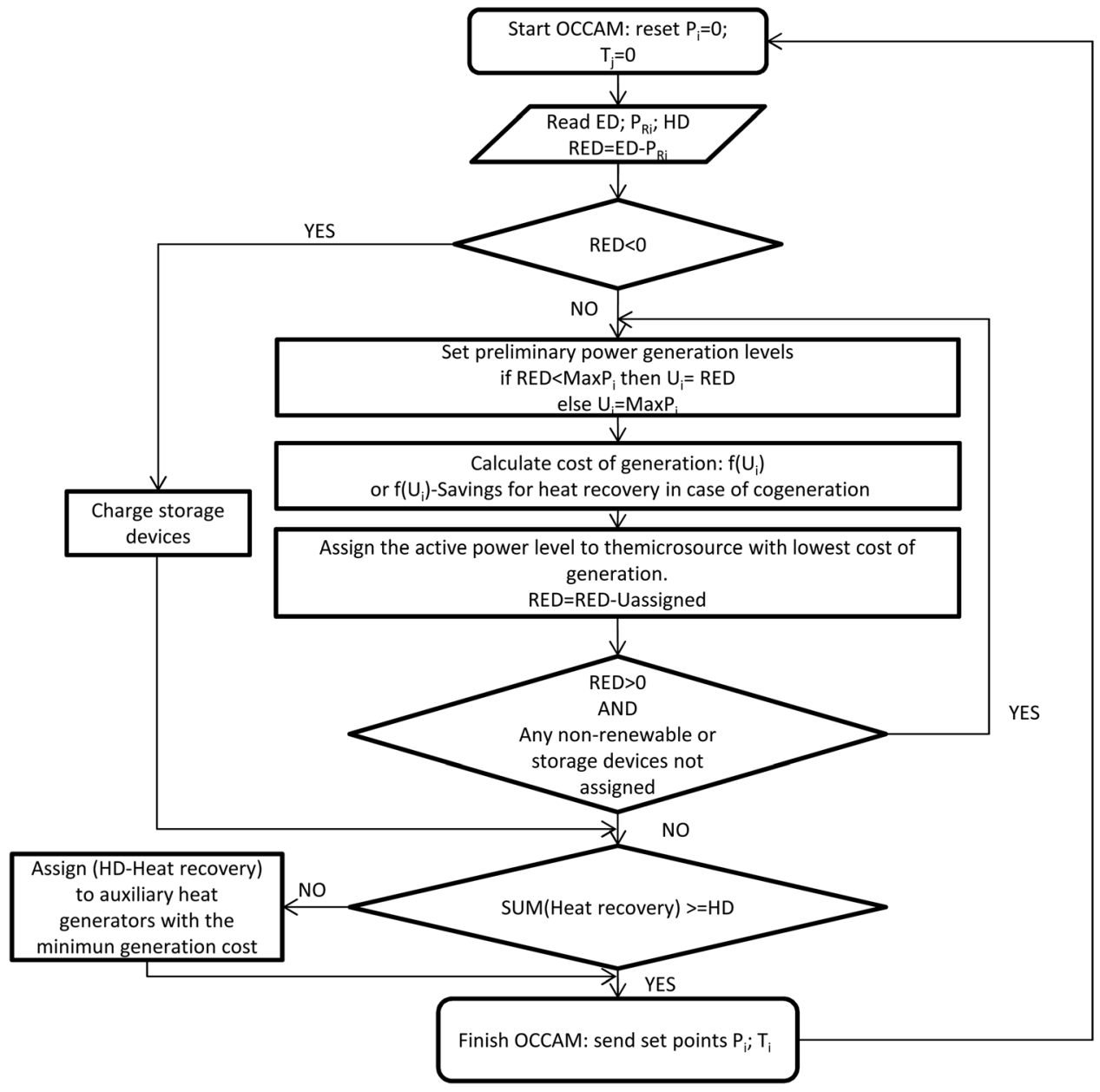

FIG. 4. OCCAM algorithm flowchart.

zero cost function (this value is not mandatory; it can be set depending on the microgrid management policy or amortization, for example). All cost functions are represented in Fig. 5.

Microsource $m_{3}$ is included in a CHP installation. The heat generated has a relationship with the active power of 2.2. $\mathrm{P}_{3}$.

There are two gas boilers of 90 and $50 \mathrm{~kW}$ to cover the heat demand. Their cost functions are (including economic and environmental cost) $\mathrm{h}_{1}\left(\mathrm{~T}_{1}\right)=0.133 \$ / \mathrm{kWh}$ and $\mathrm{h}_{2}\left(\mathrm{~T}_{2}\right)=0.149 \$ / \mathrm{kWh}$, respectively.

The electrical power demand is $59 \mathrm{~kW}$ and the heat demand is $100 \mathrm{~kW}$. The renewable microsource is producing $15 \mathrm{~kW}$ and the battery has a potential of active power production of $10 \mathrm{~kW}$.

The algorithm executes as follows:

1 st execution

- Task 0:

$\left(\mathrm{P}_{1}, \mathrm{P}_{2}, \mathrm{P}_{3}, \mathrm{P}_{4}, \mathrm{P}_{5}\right)=(0,0,0,0,0) ;\left(\mathrm{T}_{1}, \mathrm{~T}_{2}\right)=(0,0)$;

- Task 1:

$\mathrm{P}_{4}=15 \mathrm{~kW} ; \mathrm{ED}=59 \mathrm{~kW} ; \mathrm{HD}=100 \mathrm{~kW} ; \mathrm{RED}=59-15=44 \mathrm{~kW}$

- Task 2:

RED $>0 \rightarrow$ continue execution in Task 3 .

Only for not assigned non-renewable microsources or energy storage devices: 


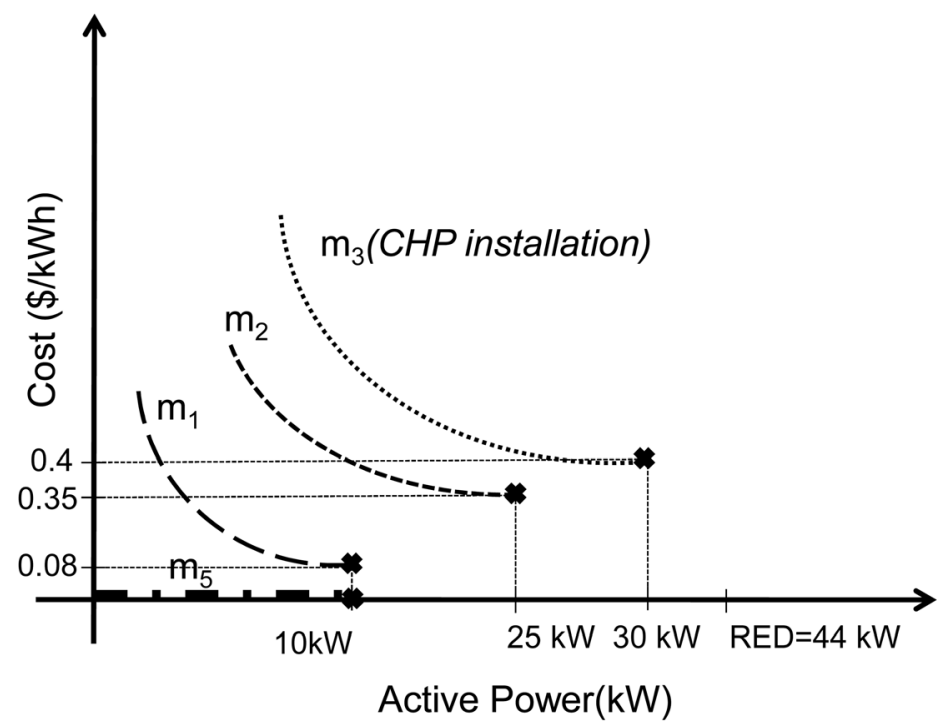

FIG. 5. Microsources cost functions and Task 3-Preliminary power generation levels.

- Task 3: Set preliminary power generation levels (Fig. 5)

$\mathrm{m}_{1}: \mathrm{RED}>10 \rightarrow \mathrm{U}_{1}=10 \mathrm{~kW}$

$\mathrm{m}_{2}: \mathrm{RED}>25 \rightarrow \mathrm{U}_{2}=25 \mathrm{~kW}$

$\mathrm{m}_{3}: \mathrm{RED}>30 \rightarrow \mathrm{U}_{3}=30 \mathrm{~kW}$

$\mathrm{m}_{5}: \mathrm{RED}>10 \rightarrow \mathrm{U}_{5}=10 \mathrm{~kW}$

- Task 4: Calculate generation cost of each microsource.

$\mathrm{f}_{1}\left(\mathrm{U}_{1}\right)=0.08 \$ / \mathrm{kWh}$

$\mathrm{f}_{2}\left(\mathrm{U}_{2}\right)=0.35 \$ / \mathrm{kWh}$

$\mathrm{f}_{3}\left(\mathrm{U}_{3}\right)$-savings $\left(\mathrm{U}_{3}\right)=0.4-\operatorname{savings}\left(\mathrm{U}_{3}\right)=0.4-0.2926=0.1074(\$ / \mathrm{kWh})$

The savings are calculated as follows:

Heat recovered in CHP installation $=2 \cdot 2 \cdot \mathrm{U}_{3}=2.2 \cdot 30=66 \mathrm{~kW} \leq 100 \mathrm{~kW}$ (heat demand)

Minimum cost to produce heat recovered using boilers,

$\mathrm{h}_{1}\left(\mathrm{~T}_{1}\right)<\mathrm{h}_{2}\left(\mathrm{~T}_{2}\right) \rightarrow \mathrm{T}_{1}=66 \mathrm{~kW} ; \mathrm{T}_{2}=0 \mathrm{~kW}$

Heat production cost $=\mathrm{h}_{1}\left(\mathrm{~T}_{1}\right) \cdot \mathrm{T}_{1}+\mathrm{h}_{2}\left(\mathrm{~T}_{2}\right) \cdot \mathrm{T}_{2}=0.133 \cdot 66+0=8.778 \$ / \mathrm{h}$

Heat production cost per electrical kWh: Savings $\left(\mathrm{U}_{3}\right)=8.778 / \mathrm{U}_{3}=0.2926 \$ / \mathrm{kWh}$

$\mathrm{f}_{5}\left(\mathrm{U}_{5}\right)=0$

- Task 5: Assign active power level to the microsource with lowest cost of generation (Fig. 6).

$\mathrm{P}_{5}=\mathrm{U}_{5}=10 \mathrm{~kW}$

$\mathrm{RED}=44-10=34 \mathrm{~kW}$

- Task 6: RED $>0$ and $\mathrm{m}_{1}, \mathrm{~m}_{2}$, and $\mathrm{m}_{3}$ without assignation $\rightarrow$ the algorithm continues its execution in Task 3.

2nd execution

$\left(\mathrm{P}_{1}, \mathrm{P}_{2}, \mathrm{P}_{3}, \mathrm{P}_{4}, \mathrm{P}_{5}\right)=(0,0,0,15,10)$

- Task 3:

$\mathrm{m}_{1}: \mathrm{RED}>10 \rightarrow \mathrm{U}_{1}=10 \mathrm{~kW}$

$\mathrm{m}_{2}: \mathrm{RED}>25 \rightarrow \mathrm{U}_{2}=25 \mathrm{~kW}$

$\mathrm{m}_{3}: \mathrm{RED}>30 \rightarrow \mathrm{U}_{3}=30 \mathrm{~kW}$

- Task 4:

$\mathrm{f}_{1}\left(\mathrm{U}_{1}\right)=0.08 \$ / \mathrm{kWh}$

$\mathrm{f}_{2}\left(\mathrm{U}_{2}\right)=0.35 \$ / \mathrm{kWh}$

$\mathrm{f}_{3}\left(\mathrm{U}_{3}\right)-$ Savings $\left(\mathrm{U}_{3}\right)=0.4-0.2926=0.1074(\$ / \mathrm{kWh})$ 


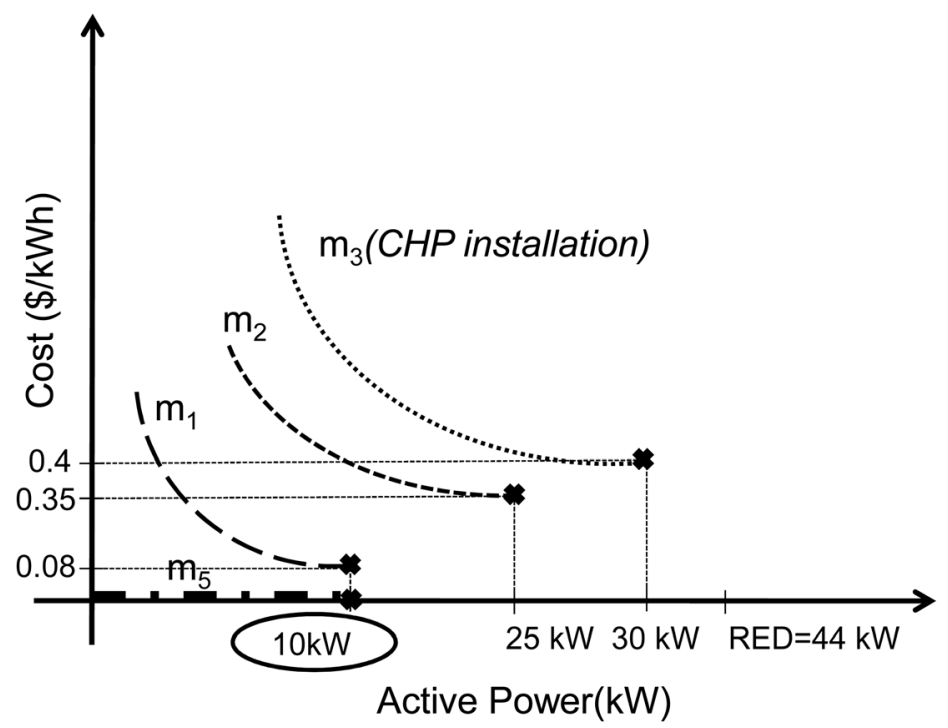

FIG. 6. Task 5-1st execution.

- Task 5 (Fig. 7):

$\mathrm{P}_{1}=\mathrm{U}_{1}=10 \mathrm{~kW}$

$\mathrm{RED}=34-10=24 \mathrm{~kW}$

- Task 6: RED $>0$ and $m_{2}$ and $m_{3}$ without assignation $\rightarrow$ the algorithm continues its execution in Task 3.

3rd execution

$\left(\mathrm{P}_{1}, \mathrm{P}_{2}, \mathrm{P}_{3}, \mathrm{P}_{4}, \mathrm{P}_{5}\right)=(10,0,0,15,10)$

- Task 3:

$\mathrm{m}_{2}: \mathrm{RED}<25 \rightarrow \mathrm{U}_{1}=24 \mathrm{~kW}$

$\mathrm{m}_{3}: \mathrm{RED}<30 \rightarrow \mathrm{U}_{2}=24 \mathrm{~kW}$ (Fig. 8)

- Task 4:

$\mathrm{f}_{2}\left(\mathrm{U}_{2}\right)=0.45 \$ / \mathrm{kWh}$

$\mathrm{f}_{3}\left(\mathrm{U}_{3}\right)-$ Savings $\left(\mathrm{U}_{3}\right)=0.5-0.2926=0.2074(\$ / \mathrm{kWh})$. In this case the heat recovered is $2.2 \cdot 24=52.8 \mathrm{~kW}$

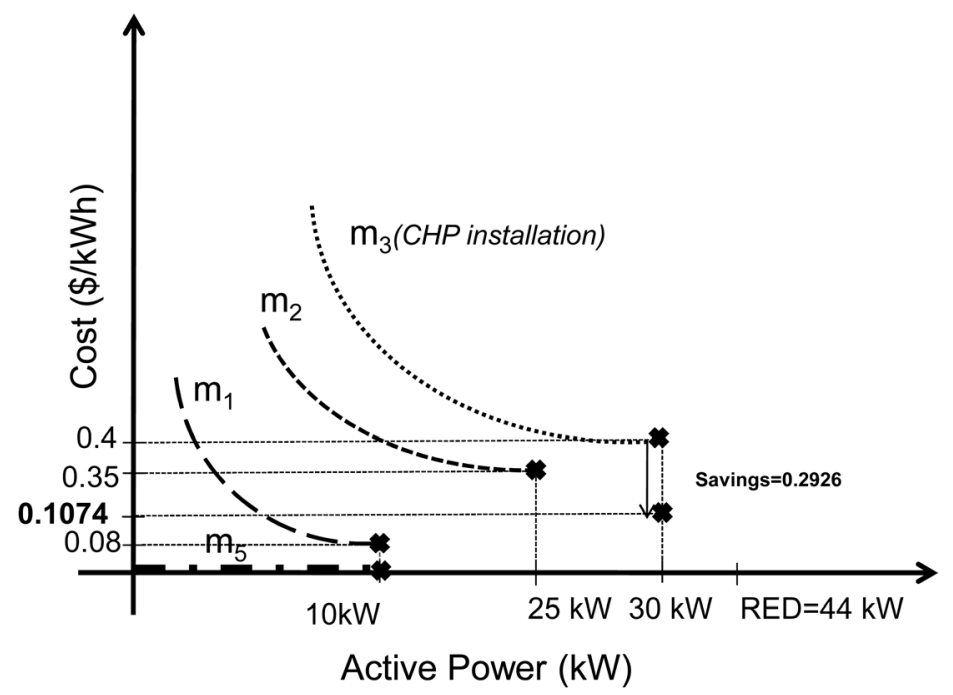

FIG. 7. Task 5-2nd execution. 


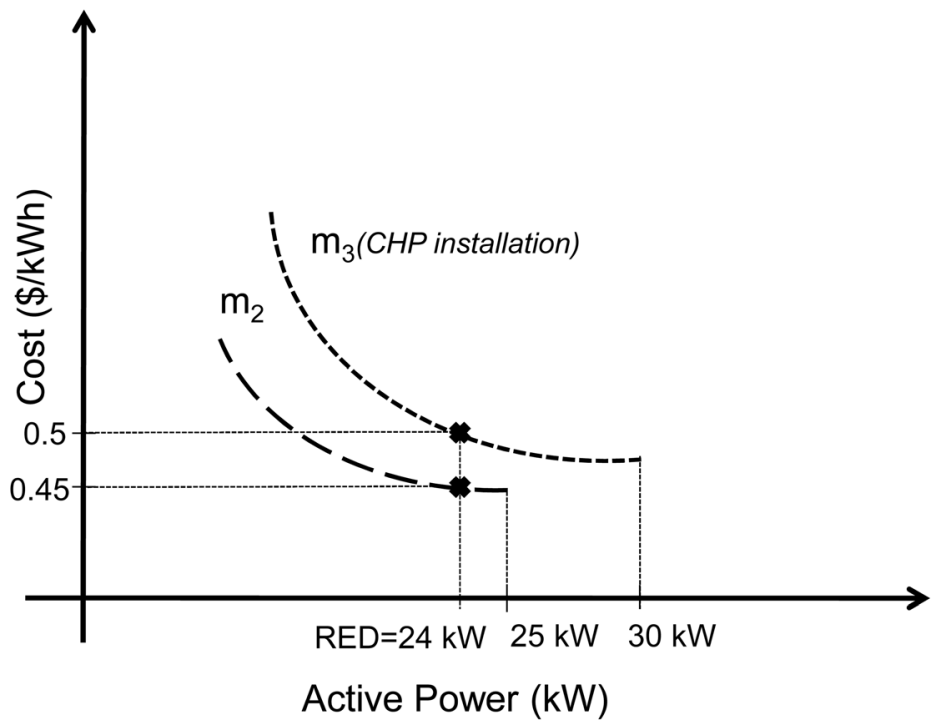

FIG. 8. Task 3-3rd execution.

- Task 5 (Fig. 9):

$\mathrm{P}_{3}=\mathrm{U}_{3}=24 \mathrm{~kW}$

$\mathrm{RED}=24-24=0$

- Task 6: $\mathrm{RED}=0 \mathrm{~kW} \Rightarrow$ algorithm continues in Task 7.

- Task 7: Distribute heat generators set-points.

Remaining heat demand $=100-52.8=47.2 \mathrm{~kW}>0$

As $h_{1}\left(T_{1}\right)<h_{2}\left(T_{2}\right)$ the first heat generator assigned is $T_{1}$ which is capable to cover up to $90 \mathrm{~kW}$.

Then heat set-points are $\left(\mathrm{T}_{1}, \mathrm{~T}_{2}\right)=(47.2,0)$.

- Task 8: Send generation levels $P_{i}$ and $T_{j}$.

\section{TEST CASE FOR PERFORMANCE COMPARISON}

The test case used to compare the performance of different algorithms is based on a microgrid arrangement (Fig. 10) used in the EU Project MICROGRIDS. ${ }^{6}$ In the case selected, five

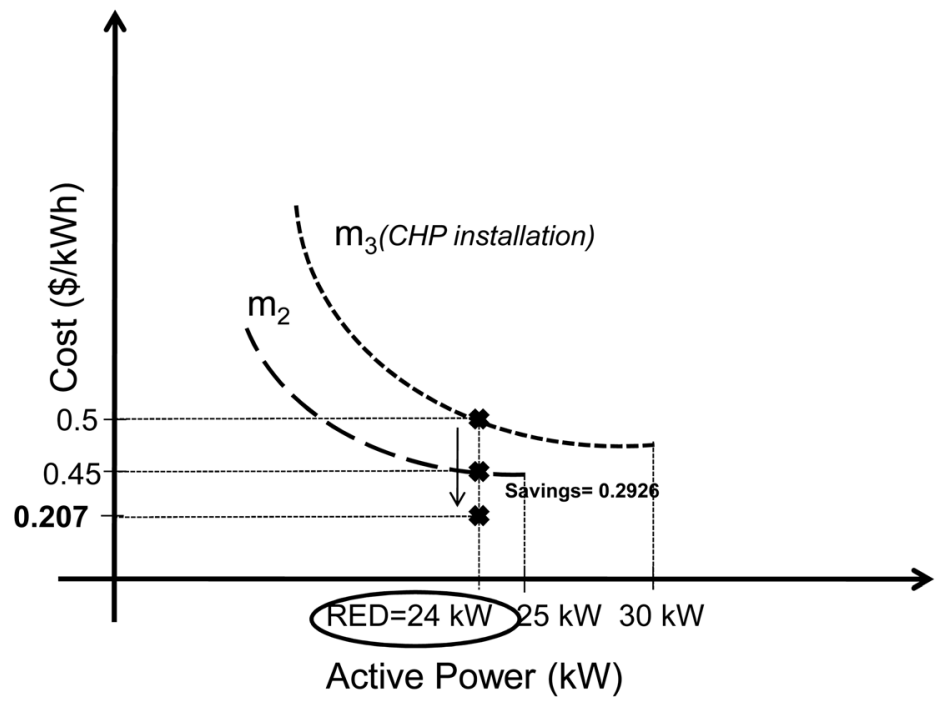

FIG. 9. Task 5-3rd execution. 


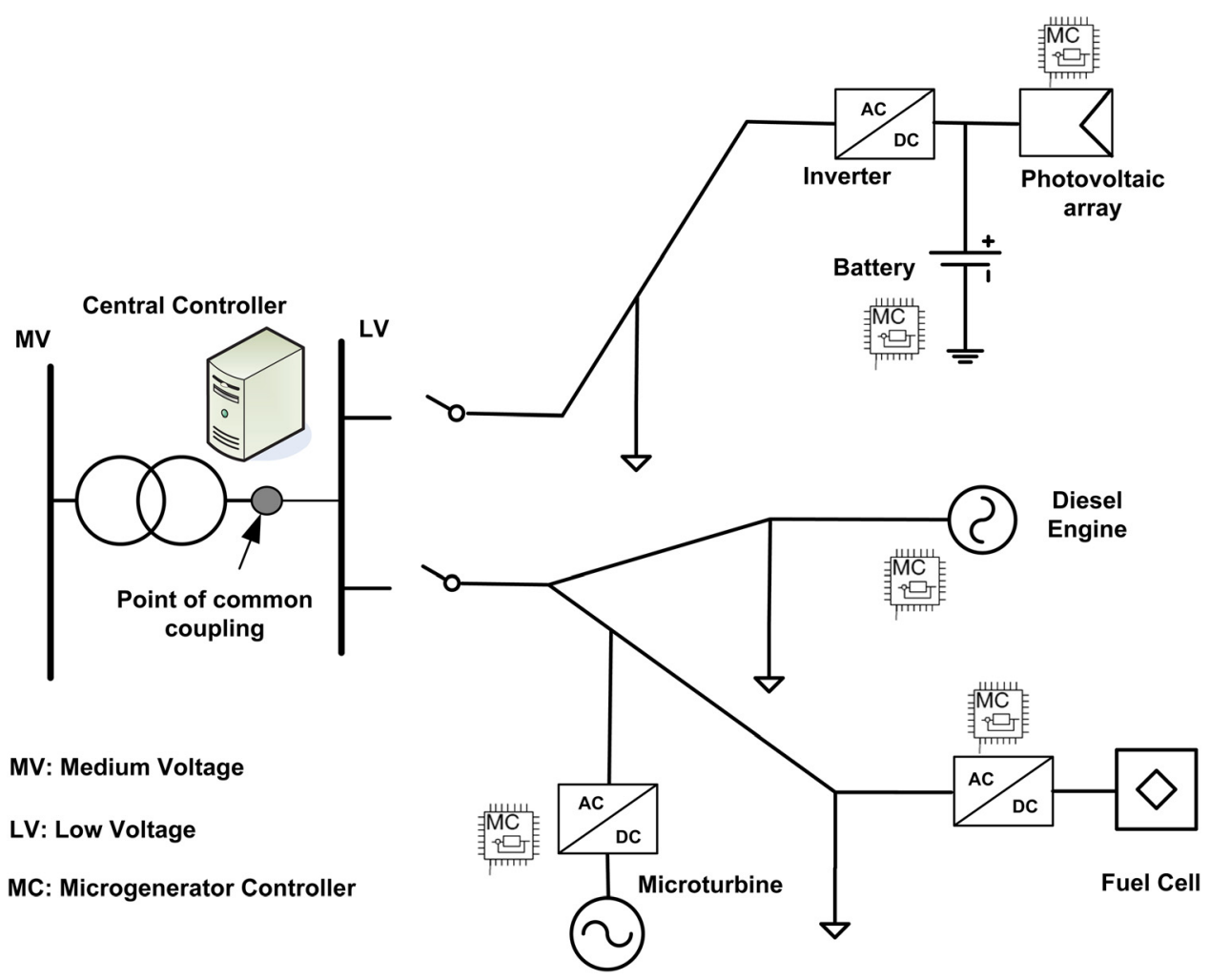

FIG. 10. Simulation platform.

microsources have been considered: a $50 \mathrm{~kW}$ proton exchange membrane fuel cell (PEM), a $30 \mathrm{~kW}$ gas microturbine in a CHP installation, a $15 \mathrm{~kW}$ diesel generator, a photovoltaic array of $20 \mathrm{~kW}$ (maximum power at standard test condition, STC), and a battery (1153 Ah, 6VDC). The auxiliary heat generator is a natural gas boiler with $200 \mathrm{~kW}$ of thermal power. These three nonrenewable microsources have been selected because of the heterogeneity of their technology. Each of these sources is sufficiently documented to determine their efficiency at each active power level of production and their dynamic behaviour.

\section{DYNAMIC MODELS OF NON-RENEWABLE MICROSOURCES}

The non-renewable microsources are modelled using a first order approach ${ }^{15,16}$ with two working modes: cold start and running mode. The model includes mechanical, electrical, and control elements.

The time constants of the model for the different microsources are shown in Table I. They have been obtained from:

- Fuel cell

The cold start and the running time constants of the fuel cell were obtained from research papers. ${ }^{17,18}$ The temperature limitation during cold start was also implemented using data from Ref. 16.

TABLE I. Time constants (s).

\begin{tabular}{lcc}
\hline \hline Microsource & Cold start mode & Running mode \\
\hline Microturbine & 200 & 7 \\
Fuel cell & 70 & 7 \\
Diesel engine & 10 & 3 \\
\hline \hline
\end{tabular}


$f(P)=0.000000000098 P^{6}-0.000000016891 P^{5}+0.000001141994 P^{4}$ $-0.000038527151 P^{3}+0.000683555628 P^{2}-0.005961748908 P+0.057296967837$

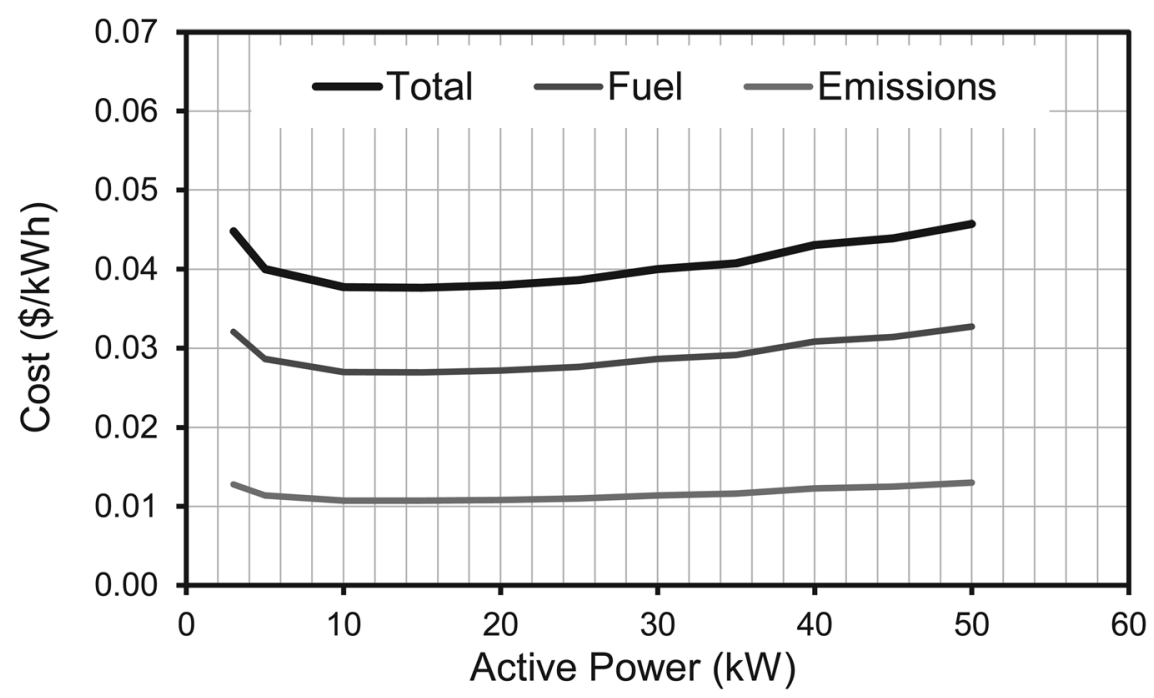

FIG. 11. Fuel cell cost functions.

- Microturbine

The time constants of the $30 \mathrm{~kW}$ microturbine, for cold start and running mode were obtained from the tests carried out in Ref. 19.

- Diesel engine

For the diesel engine model, the running mode time constant was obtained from Ref. 20 and the cold start from. ${ }^{21}$ This last value have been adjusted to account for emission, operation and the maintenance problems that a cold start may generate if it is not controlled by a smooth demand function.

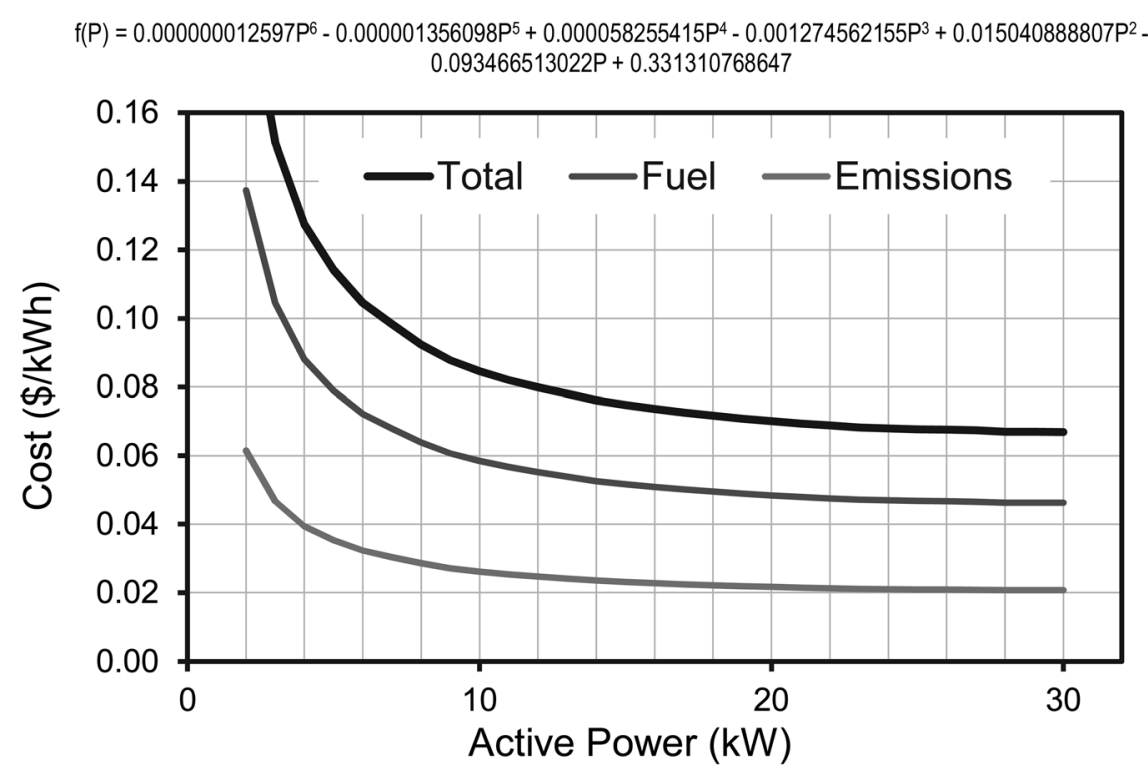

FIG. 12. Microturbine cost functions. 
$f(P)=0.000802400704 P^{2}-0.023848475991 P+0.560906049083$

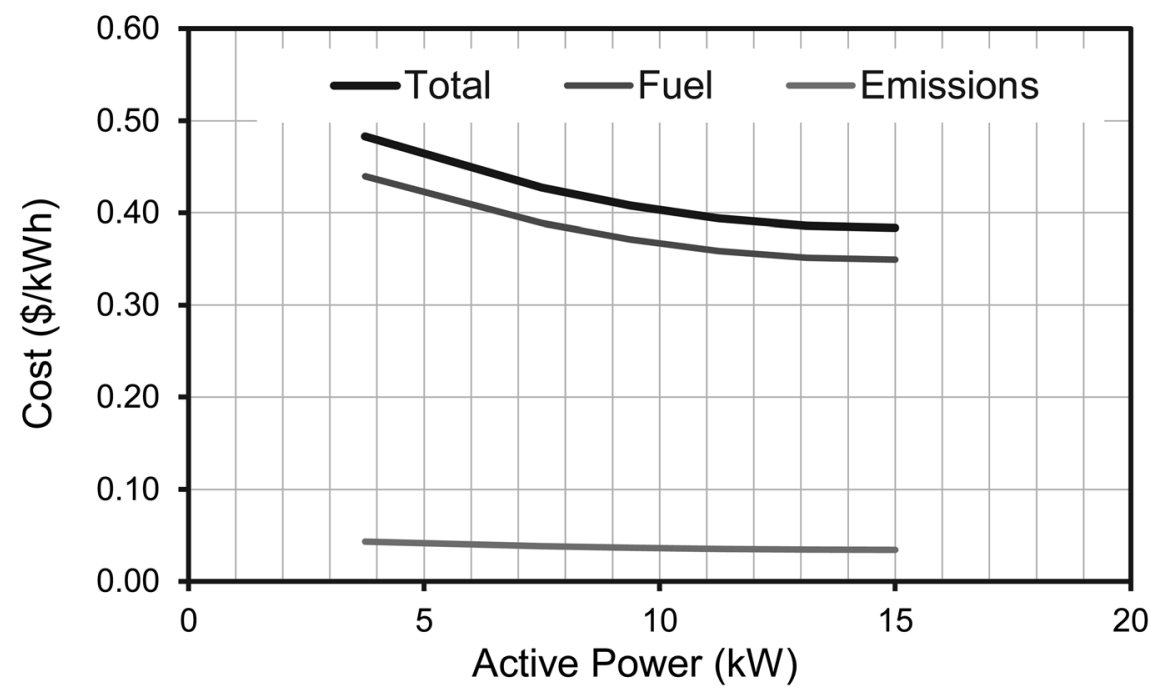

FIG. 13. Diesel engine cost functions.

\section{COST FUNCTIONS OF NON-RENEWABLE MICROSOURCES}

a) Fuel consumption cost function

Fuel consumption cost functions were obtained from current fuel prices and efficiency data available from the manufacturer technical specifications. Discrete data were converted to a continuous function using a least squares fitting.

- Fuel cell

For the fuel cell (Fig. 11), data were taken from the PEM $50 \mathrm{~kW}$ model of the Virginia Tech Laboratory. ${ }^{17}$

- Microturbine

Data from $30 \mathrm{~kW}$ microturbine Capstone C30 (Fig. 12) were taken for ISO conditions $\left(15^{\circ} \mathrm{C}\right.$, $60 \%$, relative humidity and $101.325 \mathrm{kPa}){ }^{22}$

- Diesel engine

In the case of the diesel engine (Fig. 13), a standard $15 \mathrm{~kW}$ electrical power model was selected. $^{23}$

b) Emissions cost functions

The emissions cost functions were obtained for each case using the nominal emissions factor $^{24}(\mathrm{~kg}$ pollutant $/ \mathrm{kWh})$ weighted with the fuel consumption curve, and the cost associated to the removal of each contaminant ${ }^{25}$ ( $\$ / \mathrm{kg}$ pollutant).

\section{TEST DEFINITION}

Once the simulation case was established, different tests were performed using the following parameters:

- Algorithms: MADS and SQP, and OCCAM.

- Platform: Simulink (MATLAB); CPU Intel Core Duo $1.66 \mathrm{GHz}$, and $2 \mathrm{~GB}$ of RAM.

- Electrical demand: One-day demand of 40, 80, 160, and 200 houses. ${ }^{26}$

- Heat demand: One-day demand of 40, 80, 160, and 200 houses. $^{27}$

- Power generated by the photovoltaic array ${ }^{28}$ : 


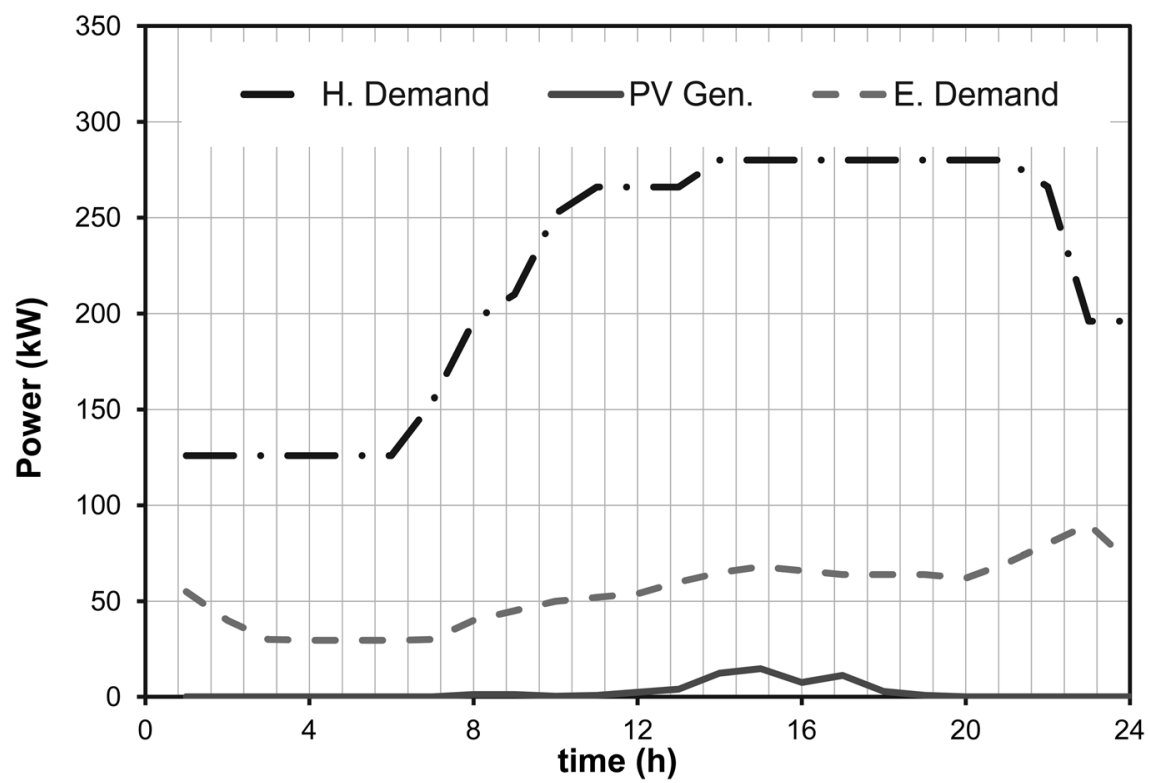

FIG. 14. One day electrical and heat demand for 200 houses; photovoltaic production.

TABLE II. Correlation coefficients.

\begin{tabular}{lcccc}
\hline \hline & 40 houses & 80 houses & 160 houses & 200 houses \\
\hline MADS & 0.098 & 0.520 & 0.880 & 0.901 \\
SQP & 0.088 & 0.540 & 0.871 & 0.901 \\
OCCAM & 0.127 & 0.597 & 0.885 & 0.974 \\
\hline \hline
\end{tabular}

TABLE III. Global costs (\$).

\begin{tabular}{lcccc}
\hline \hline & 40 houses & 80 houses & 160 houses & 200 houses \\
\hline MADS & 29.55 & 52.50 & 98.50 & 115.70 \\
SQP & 29.02 & 52.05 & 113.30 & 149.40 \\
OCCAM & 27.75 & 51.65 & 99.15 & 116.3 \\
\hline
\end{tabular}

TABLE IV. Emission costs (\$).

\begin{tabular}{lcccc}
\hline \hline & 40 houses & 80 houses & 160 houses & 200 houses \\
\hline MADS & 5.62 & 9.87 & 18.21 & 19.69 \\
SQP & 5.61 & 9.78 & 24.85 & 34.13 \\
OCCAM & 5.57 & 9.73 & 18.17 & 19.66 \\
\hline \hline
\end{tabular}


TABLE V. Average execution time (ms).

\begin{tabular}{lcccc}
\hline \hline & 40 houses & 80 houses & 160 houses & 200 houses \\
\hline MADS & 39.2 & 33.9 & 43.8 & 47.3 \\
SQP & 23.9 & 12.8 & 89 & 26.3 \\
OCCAM & 0.0404 & 0.0395 & 0.0496 & 0.0498 \\
\hline \hline
\end{tabular}

$$
\mathrm{P}_{\mathrm{PV}}=\mathrm{P}_{\mathrm{STC}} \cdot \frac{\mathrm{G}_{\mathrm{ING}}}{\mathrm{G}_{\mathrm{STC}}} \cdot\left(1-\mathrm{k} \cdot\left(\mathrm{T}_{\mathrm{C}}-\mathrm{T}_{\mathrm{R}}\right)\right)
$$

where $P_{P V}$ is the output power, $P_{S T C}$ maximum power at standard test condition, $G_{I N G}$ incident irradiance, $\mathrm{G}_{\mathrm{STC}}$ standard test irradiance, $\mathrm{k}$ coefficient of thermal power reduction, $\mathrm{T}_{\mathrm{C}}$ cell temperature, and $T_{R}$ reference temperature. Climatological data were obtained from Ref. 29.

Fig. 14 shows the electrical and heat demand together with the photovoltaic production along a whole day for the 200 houses test.

\section{RESULTS AND DISCUSSION}

From each different test the following data were obtained:

- Generation level of each microsource and heat generator along time.

- Costs per day.

- Correlation coefficient to define electrical demand adjustment.

- Processing time of the three different algorithms.

Global results are shown in Tables II-V. The best correlation coefficients were obtained using OCCAM, which means a better adjustment of the electrical generation to the demand. The high values obtained-with the three methods-imply that a transparent integration in the electrical system may be achieved. In terms of global cost, the results obtained with the three algorithms are similar, but OCCAM obtains the minimum emissions costs.

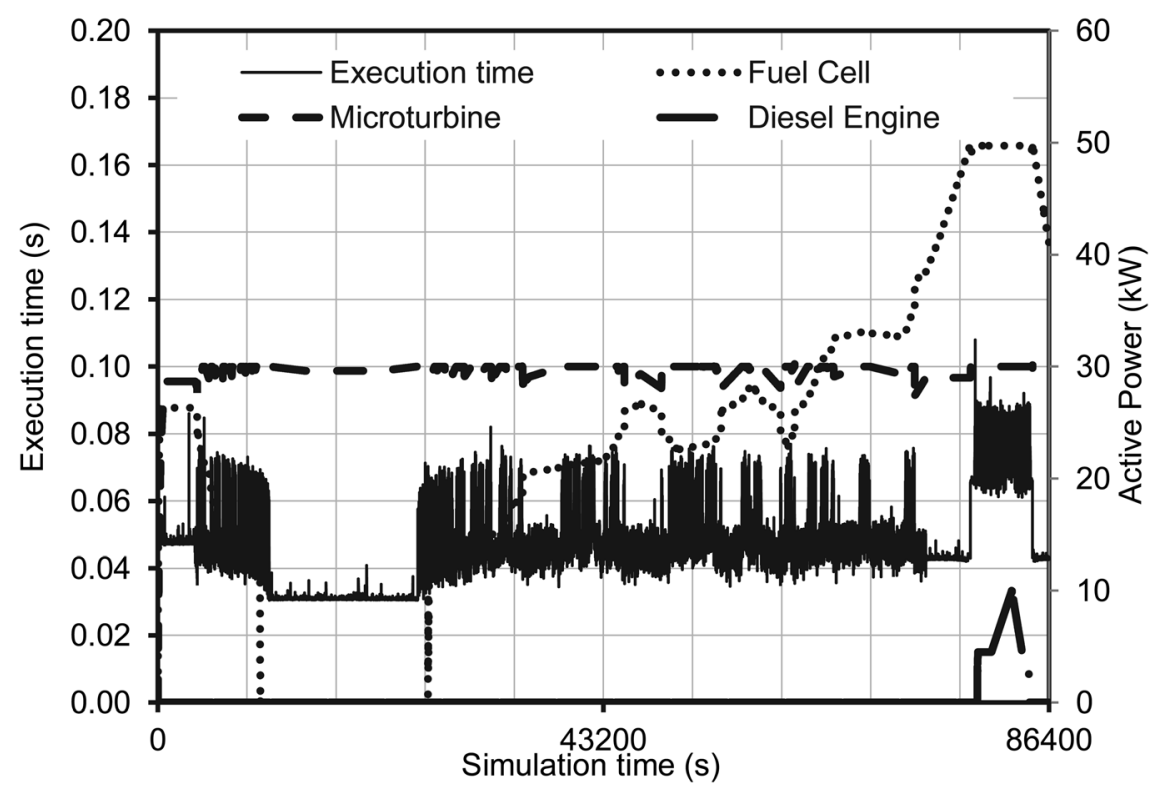

FIG. 15. MADS execution time and generation active power values (200 houses). 


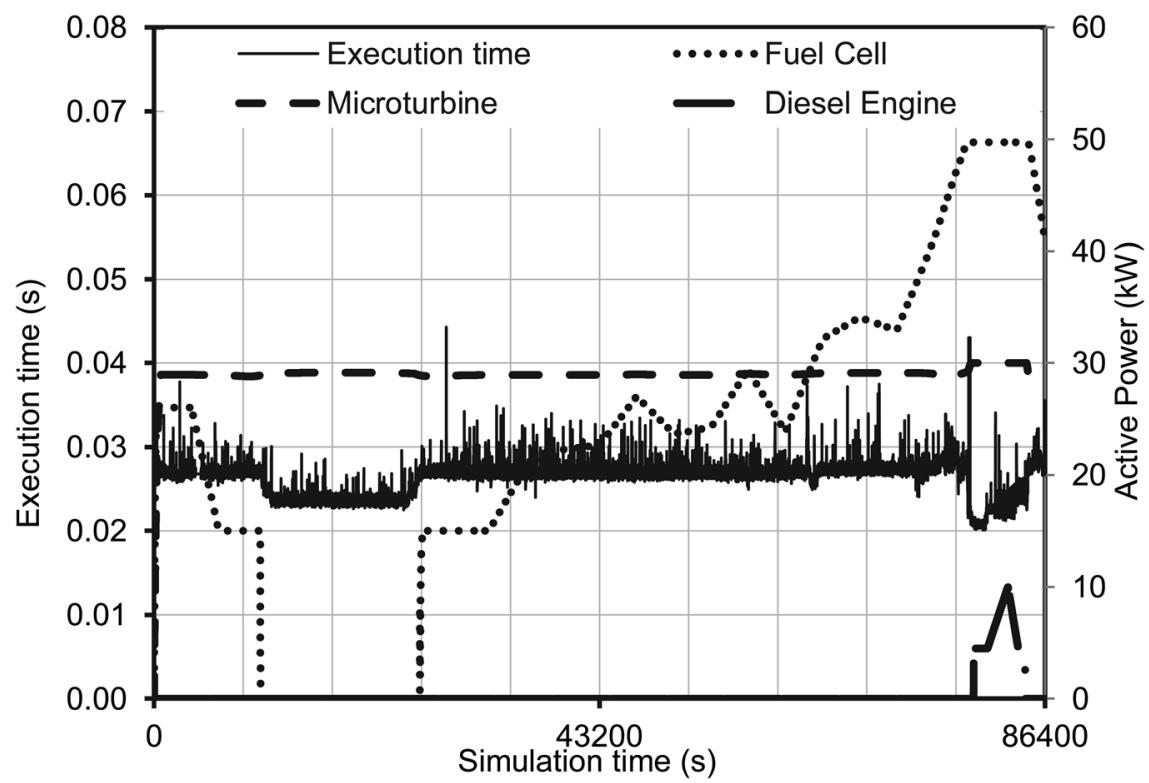

FIG. 16. SQP execution time and generation active power values (200 houses).

About the average execution times, the times obtained using the OCCAM algorithm are about three orders of magnitude lower than those obtained with the other algorithms.

Figures 15 and 16 show the single cycle execution time for the MADS and SQP algorithms, together with the power levels of non-renewable microsources along the day. The MADS algorithm has a tendency to a high oscillation of the cycle time as well as discrete increments when the number of microsources augments. This can be seen in Figure 15 when the use of the diesel engine is required $(80.000$ to $85.000 \mathrm{~s})$. The SQP has a lower range of oscillation but there are some isolated peaks, usually when the number of microsources changes. Although it has not been included in the figures, the execution time using OCCAM also has high relative oscillations but it always remains below $0.5 \mathrm{~ms}$.

The microsources set-points obtained using MADS and SQP have larger variations than those obtained using OCCAM. They not only have more microsources starts and stops but also each individual power level has significant fluctuations. This is the reason to its lower

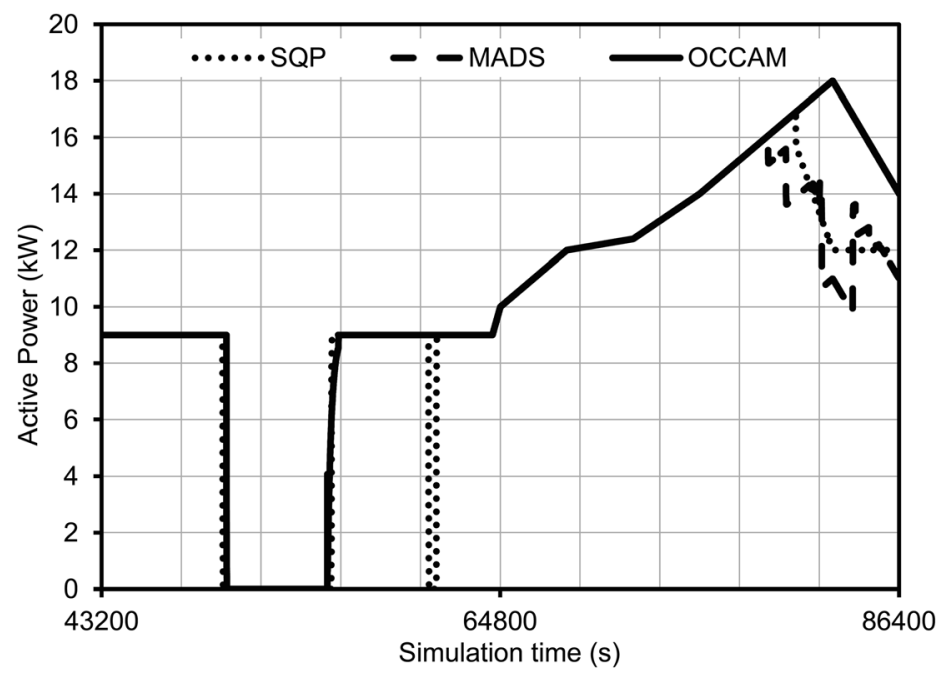

FIG. 17. Detail of the microturbine electrical power generation using the three algorithms (40 houses). 
correlation coefficients. For example, Figure 17 shows a detail of the electrical power produced by the microturbine in the test with 40 houses.

\section{CONCLUSIONS}

This research describes and presents the results of a new algorithm (OCCAM) for active power and heat dispatch in connected-to-the-grid microgrids. The algorithm is based on the heuristic minimization of microsources costs functions. The algorithm has been compared with state of the art of non-linear optimization methods (MADS, SQP) using a test case based on the MICROGIDS project ${ }^{6}$ and different electrical and heat daily demands.

The performance obtained using OCCAM is similar or even better than that obtained using MADS and SQP in terms of economic costs and transparent integration in the distribution system.

However, the proposed method has shown two significant improvements. First, the OCCAM algorithm achieves minimum emission costs with better microsource stability. Second, the execution time is about three orders of magnitude lower, and it is easy to implement in an off-the-shelf controller. That makes the algorithm suitable to on-line running in a centralized microgrid management system.

${ }^{1}$ M. Mohammadi, S. H. Hosseinian, and G. B. Gharehpetian, "Optimal sizing of micro grid and distributed generation units under pool electricity market,” J. Renewable Sustainable Energy 2011, 053103 (2011).

${ }^{2}$ S. M. Moghaddas-Tafreshi, H. A. Zamani, and S. M. Hakimi, "Optimal sizing of distributed resources in a micro grid with loss of power supply probability technology by using breeding particle swarm optimization," J. Renewable Sustainable Energy 2011, 043105 (2011).

${ }^{3}$ F. Katiraei, R. Iravani, N. Hatziargyriou, and A. Dimeas, "Microgrids management," Power Energy Mag. IEEE 6(3), 54-65 (2008).

${ }^{4}$ R. Zamora and A. K. Srivastava, "Controls for microgrids with storage: Review, challenges, and research needs," Renewable Sustainable Energy Rev. 14(7), 2009-2018 (2010).

${ }^{5}$ P. Piagi and R. H. Lasseter, "Autonomous control of microgrids," in Proceedings of the IEEE Power Engineering Society General Meeting (IEEE, 2006), p. 8.

${ }^{6}$ See http://www.microgrids.eu for Microgrids European Research Project.

${ }^{7}$ N. D. Hatziargyriou, A. Dimeas, A. G. Tsikalakis, J. A. P. Lopes, G. Karniotakis, and J. Oyarzabal, "Management of microgrids in market environment," IEEE International Conference on Future Power Systems (IEEE, 2005), p. 7.

${ }^{8}$ A. Bagherian and S. M. M. Tafreshi, "A developed energy management system for a microgrid in the competitive electricity market," in PowerTech 2009 (IEEE Bucharest, 2009), pp. 1-6.

${ }^{9}$ C. A. Hernandez-Aramburo, T. C. Green, and N. Mugniot, "Fuel consumption minimization of a microgrid," IEEE Trans. Ind. Appl. 41(3), 673-681 (2005).

${ }^{10}$ F. A. Mohamed, Microgrid Modelling and Online Management (Helsinki University of Technology, 2008), see also http://lib.tkk.fi/Diss/2008/isbn9789512292356/.

${ }^{11}$ F. A. Mohamed and H. N. Koivo, "System modelling and online optimal management of microgrid using multiobjective optimization," in Proceedings of International Conference on Clean Electrical Power (IEEE, 2007), pp.148-153.

${ }^{12}$ S. J. Ahn and S. I. Moon, "Economic scheduling of distributed generators in a microgrid considering various constraints," in Proceedings of the PES'09 IEEE Power and Energy Society General Meeting (IEEE, 2009), pp. 1-6.

${ }^{13}$ R. H. Lasseter, A. Akhil, C. Marnay, J. Stephens, J. Dagle, G. Guttomson et al., The CERTS Microgrid Concept White Paper for Transmission Reliability Program (Office of Power Technologies, U.S. Department of Energy, 2002).

${ }^{14}$ R. H. Lasseter, "MicroGrids," in Proceedings of PES Winter Meeting (IEEE, 2002), vol. 1, pp. 305-308.

${ }^{15}$ R. Lasseter, K. Tomsovic, and P. Piagi, "Scenarios for distributed technology applications with steady state and dynamic models of loads and micro-sources," Consortium for Electric reliability Technology Solutions, April 2000, see also http://certs.lbl.gov/certs-der-pubs.html.

${ }^{16} \mathrm{~S}$. Obara, "Dynamic characteristic of a fuel cell micro-grid using an engine generator to base load operation," J. Environ. Eng. 3(1), 49-60 (2008).

${ }^{17}$ S. Gurski, Cold Start Effects on Performance and Efficiency for Vehicle Fuel Cell Systems (Virginia Polytecnic Institute and State University, 2002), see also http://scholar.lib.vt.edu/theses/available/etd-12192002-16162600/unrestricted/ sgurski@vt.edu_thesis.pdf.

${ }^{18}$ M. Y. El Sharkh, N. S. Sisworahardjo, M. Uzunoglu, O. Onar, and M. S. Alam, "Dynamic behavior of PEM fuel cell, and microturbine power plants," J. Power Sources 164(1) 315-321 (2007).

${ }^{19}$ A. Y. Petrov, A. Zaltash, and S. D. Labinov, "Dynamic performance of a $30 \mathrm{~kW}$ microturbine-based CHP system," in Proceedings of ASHRAE Winter Meeting, 5-9 February 2005.

${ }^{20}$ B. Palle, C. Uriarte, M. G. Simoes, and S. Chakraborty, Electrical Model Development and Validation for Distributed Resources, NREL National Renewable Energy Laboratory, Subcontract Report NREL/SR-581-41109, April 2007, [Online], available at http://www.nrel.gov/docs/fy07osti/41109.pdf.

${ }^{21}$ A. M. Lippert, D. W. Stanton, C. J. Rutland, W. L. H. Hallet, and R. D. Reitz, "Multidimensional simulation of diesel engine cold start with advanced physical submodels," Int. J. Engine Res. 1(1), (2000), pp. 1-27.

${ }^{22} \mathrm{See}$ http://www.capstoneturbine.com for Capstone Turbine Corporation, European Office, 6 Holme Road, West Bridgford, Nottingham, NG2 5AA, England, UK.

${ }^{23}$ See http://www.generatorjoe.net for GeneratorJoe Inc., 4016 Quartz Drive, Santa Rosa, California 95405, USA. 
${ }^{24}$ I. F. Roth and L. Ambs Lawrence, "Incorporating externalities into a full approach to electric power generation life-cycle costing," Energy Int. J. 29(12-15), 1835-2617 (2004).

${ }^{25}$ See http://www.raponline.org for The Regulatory Assistance Project, model regulations for the output of specified air emissions from smaller-scale electric generation resources, 2002.

${ }^{26} \mathrm{See}$ http://www.ree.es/sistema_electrico/pdf/indel/Atlas_INDEL_REE.pdf for Red Eléctrica de España, Indel Project. Atlas de la demanda eléctrica española, 1998.

${ }^{27}$ W. Gilijamse and M. E. Boonstra, "Energy efficiency in new houses. Heat demand reduction versus cogeneration," Energy Buildings 23, 49-62 (1995).

${ }^{28} \mathrm{~S}$. Meliopoulos, Challenges in simulation and design of grids, in Proceedings of IEE/PES Winter Meeting, New York, 27-31 January 2002.

${ }^{29} \mathrm{See}$ http://www.aemet.es for Agencia Estatal de Meteorología (AEMET), Irradiance 12 of September 2006 Murcia. 